\title{
METHIONINE GENES AND ENZYMES OF SALMONELLA TYPHIMURIUM
}

\author{
D A SMITH* and J. D CHILDS $\dagger$ \\ Department of Microbiology, Birmingham University
}

Received 28.viii.65

\section{INTRODUCTION}

THE combined genetical and biochemical studies of large numbers of similar auxotrophs and other mutants of Salmonella typhimurium LT-2 initiated by Demerec and his associates (Demerec, Blomstrand and Demerec, 1955; Demerec and Demerec, 1955; Hartman, 1956) has yielded, amongst other things, much information on genetic fine structure (Demerec and Hartman, 1959), the arrangement of genes with respect to functions (Hartman, Loper and Šrman, ig6o) and the control of protein synthesis (Ames and Hartman 1963). One of the most striking features of this work has been the demonstration of close linkage or clustering of genes concerned with related functions (Demerec and Demerec, 1955; Glanville and Demerec, 1960; Ames and Hartman, 1963; Margolin, 1963) which is compatible with the operon model for the control of protein synthesis (Jacob and Monod, r96I) and its modifications (Ames and Martin, 1964 ).

Preliminary work with less than 50 methionine mutants of $S$. typhimurium LT-2 led to the recognition of five genes concerned with imprecisely defined steps in the biosynthesis of methionine (Glover, 1958; Smith, 1961). Only two of these genes were close enough to be co-transduced (Smith, 1961). The clustering of methionine genes therefore appeared to be very limited and it was thought desirable to investigate the system further. As about 200 more methionine mutants became available they, and those previously used, were investigated genetically and biochemically with the aim of identifying new genes, investigating as far as possible the enzymic deficiencies of all methionine genes, analysing the fine structure of each of them and relating the results of these studies to the location of the genes on the bacterial chromosome. This work was aided greatly by the precise definition of the pathway of methionine biosynthesis firstly in Escherichia coli (Wijesundera and Woods, 1962; Rowbury and Woods, 1964 ; Woods, Foster and Guest, 1965) and then in S. typhimurium (Foster, personal communication; Flavin, Delavier-Klutchko and Slaughter, 1964; Rowbury, 1964a). The mapping studies using Hfr conjugation techniques were carried out elsewhere (Sanderson and Demerec, 1965).

The system of nomenclature and terminology is the same as that used previously (Smith, I96I) except that mutant symbols have been

\footnotetext{
* Department of Genetics, Birmingham University.

$\uparrow$ Microbiology Unit, Department of Biochemistry, Oxford.
} 


\section{modified to coincide with the alterations of Sanderson and Demerec} ( 1965 , table 7).

\section{MATERIALS AND METHODS}

Bacteria, phage and media. All of the 243 different methionine (met) mutants used (table I) were derived either from wild type or auxotrophic mutants of Salmonella typhimurium strain LT-2. Forty-four (met2-68 inclusive) had been used previously (Smith, I961, table I) and 199 (met69-422 inclusive) were newly isolated either as spontaneous mutants or following X-ray, ultra-violet, 2-aminopurine or diethyl sulphate induction. One hundred and ninety-five of the new mutants were obtained from Dr M. Demerec, Brookhaven National Laboratory, Upton, Long Island, New York, one from Professor Stocker, Lister Institute, Chelsea Bridge Road, London (met 422 , originally SL $5^{82}$ ) and three in this department (met419, 420 and 421 ).

The maintenance of stock cultures, the preparation and centrifugation of liquid cultures of bacteria, the testing of the growth responses of mutants to methionine intermediates, the demonstration of cross-feeding between mutants and the preparation and assay of suspensions of phage PLT-22 $\left(\mathrm{P}_{2-2}\right)$ were as previously described (Smith, I961). The media used were also the same except that Oxoid Nutrient Broth and Nutrient Agar (NA) were used as additional nutrient media and the minimal medium (MM) was supplemented when required with the following additional growth factors at a final concentration of $20 \mu \mathrm{g} . / \mathrm{ml}$.: DL-allo cystathionine, Larginine $\mathrm{HCl}$, L-histidine $\mathrm{HCl}$, L-proline and L-tyrosine.

Heat sensitivity. This was tested by streaking loopfuls of two saline suspensions containing approximately $2 \times 10^{8}$ and $2 \times 10^{4}$ orgs. $/ \mathrm{ml}$. respectively onto two plates of minimal agar (MA) or appropriately supplemented MA medium and incubating one plate at $37^{\circ} \mathrm{C}$. and the other at $25^{\circ} \mathrm{C}$. Observations were made during four days incubation. Mutants were designated heat sensitive if the growth of both inocula after two days incubation was clearly visible and similar to that of wild type at $25^{\circ} \mathrm{C}$. but negligible at $37^{\circ} \mathrm{C}$.

Transduction. In addition to a standard transduction technique for met mutants previously described (Smith, 196r) a method was devised for the rapid detection of complete and abortive transduction (i.e. recombination and complementation) between large numbers of mutants. It was similar to that of Hartman, Hartman and Šrman (1960). Up to 9 crosses could be carried out on a Petri plate of $9 \mathrm{~cm}$. diameter. Overnight broth cultures of the recipient strains were centrifuged and resuspended in $\mathrm{I} / \mathrm{roth}$ volume of broth $\left(c .2 \times \mathrm{1}^{10} \mathrm{orgs} . / \mathrm{ml}\right.$. $)$ and $0 \cdot 1 \mathrm{ml}$. quantities spread evenly on the surface of MA plates which had been dried for three or four days at $37^{\circ} \mathrm{C}$. When the inocula had soaked in, drops of donor phage preparations containing $c .1 \times 10^{10}$ particles were placed on the surface of the plates with Pasteur pipettes. They each covered an area of $\mathrm{I}-\mathrm{I} \cdot 5 \mathrm{~cm}$. diameter. These plates were then incubated for $4^{8}$ hours at $25^{\circ} \mathrm{C}$. or $37^{\circ} \mathrm{C}$., depending upon the met mutants used. Transduction of met mutants with a wild type donor or between mutants of different met genes gave 40-100 recombinant colonies per area and that between mutants of the same met gene 0-20. The diameter of the colonies varied from $0 \cdot 5-2 \mathrm{~mm}$. Minute colonies of $0 \cdot 035-0.05 \mathrm{~mm}$. diameter resulting from abortive transduction could also be detected with a binocular stereoscopic microscope ( $\times 25$ magnification). They were more easily visible after keeping the plates for a further 24 hours at room temperature.

\section{RESULTS}

\section{(i) The gene deficiencies of new mutants}

The gene deficiencies of most of the 199 new methionine mutants were identified (table I) on the basis of their growth responses to known intermediates in the biosynthesis of methionine and the frequency of transduction between them and representative mutants of the 5 
TABLE I

Methionine (met) mutants of Salmonella typhimurium

\begin{tabular}{|c|c|c|c|c|c|c|c|}
\hline \multicolumn{8}{|c|}{ metA } \\
\hline Mutant & Other markers & Mod & of origin & Reversio & Index & & er properties \\
\hline  & $\begin{array}{l}\text { cysA2I } \\
\text { cysBI2 } \\
\\
\text { tryA8 } \\
\text { tryA8 } \\
\text { tryB? } \\
\text { purG2 } \\
\text { purEII } \\
\text { purEII } \\
\\
\\
\\
\\
\\
\\
\\
\text { arag } \\
\text { arag } \\
\text { arag } \\
\text { arag } \\
\text { arag } \\
\\
\\
\text { arag } \\
\text { arag } \\
\text { arag } \\
\text { arag } \\
\text { arag } \\
\text { arag } \\
\text { arag } \\
\text { arag } \\
\text { arag }\end{array}$ & . & $\begin{array}{l}\mathrm{u} / \mathrm{v} \\
\mathrm{u} / \mathrm{v} \\
\mathrm{a} / \mathrm{v} \\
\mathrm{p} \\
\mathrm{p} \\
\mathrm{p} \\
\mathrm{p} \\
\mathrm{p} \\
\mathrm{p} \\
\mathrm{sp} \\
\mathrm{pp} \\
\mathrm{p} \\
\mathrm{p} \\
\mathrm{p} \\
\mathrm{p} \\
\mathrm{pp} \\
\mathrm{sp} \\
\mathrm{u} / \mathrm{v} \\
\mathrm{sp} \\
\mathrm{u} / \mathrm{v} \\
\mathrm{sp} \\
\mathrm{sp} \\
\mathrm{sp} \\
2 a p \\
2 a p \\
2 a p \\
2 a p \\
2 \mathrm{ap} \\
2 \mathrm{ap} \\
2 \mathrm{ap} \\
2 \mathrm{ap} \\
\mathrm{X} \\
\mathrm{X} \\
\mathrm{X} \\
\mathrm{X} \\
\mathrm{X} \\
\mathrm{X} \\
\mathrm{X} \\
\mathrm{X} \\
\mathrm{X} \\
\mathrm{sp} \\
2 \mathrm{p} \\
2 \mathrm{ap} \\
2 \mathrm{ap} \\
2 \mathrm{p}\end{array}$ & $\begin{array}{r}0 \\
+ \\
0 \\
0 \\
+ \\
+ \\
0 \\
+ \\
0 \\
+ \\
+ \\
+ \\
++ \\
+ \\
+ \\
0 \\
+ \\
+ \\
+ \\
+ \\
+ \\
+ \\
+ \\
+ \\
+ \\
+ \\
+ \\
+ \\
+ \\
+ \\
+ \\
+ \\
+ \\
+ \\
+ \\
+ \\
+ \\
+ \\
+ \\
+ \\
+ \\
+ \\
+\end{array}$ & & & $\begin{array}{l}\mathrm{dl} \\
\mathrm{dl} \\
\text { lys } \\
\text { hs } \\
\mathrm{dl} \\
\mathrm{dl} \\
\text { hs }\end{array}$ \\
\hline \multicolumn{8}{|c|}{$m e t B$} \\
\hline Mutant & $\begin{array}{l}\text { Other } \\
\text { markers }\end{array}$ & $\begin{array}{l}\text { Aode of } \\
\text { origin }\end{array}$ & $\begin{array}{r}\text { Comple } \\
\mathrm{gr}\end{array}$ & entation & $\begin{array}{r}\text { Revers } \\
\text { inde }\end{array}$ & & $\begin{array}{l}\text { Other } \\
\text { properties }\end{array}$ \\
\hline $\begin{array}{c}6 \\
16 \\
17 \\
20 \\
23 \\
34 \\
36 \\
39 \\
41 \\
45\end{array}$ & $\begin{array}{l}\text { cysBi6 } \\
\text { cysBI6 } \\
\text { tryA8 } \\
\\
\text { purG2 } \\
\text { purG2 } \\
\text { purG2 } \\
\text { purEII } \\
\text { purEII }\end{array}$ & $\begin{array}{l}\mathrm{u} / \mathrm{v} \\
\mathrm{sp} \\
\mathrm{sp} \\
\mathrm{sp} \\
\mathrm{sp} \\
\mathrm{sp} \\
\mathrm{sp} \\
\mathrm{sp} \\
\mathrm{sp} \\
\mathrm{sp}\end{array}$ & & $\begin{array}{l}\mathrm{L} \\
\mathrm{G}\end{array}$ & $\begin{array}{c}+ \\
++ \\
++ \\
+ \\
+ \\
+ \\
0 \\
+ \\
+ \\
+\end{array}$ & & dl \\
\hline
\end{tabular}


TABLE I-(Continued)

\begin{tabular}{|c|c|c|c|c|c|}
\hline \multicolumn{6}{|c|}{$\operatorname{met} B$} \\
\hline Mutant & $\begin{array}{l}\text { Other } \\
\text { markers }\end{array}$ & $\begin{array}{l}\text { Mode of } \\
\text { origin }\end{array}$ & $\begin{array}{l}\text { Complementation } \\
\text { group }\end{array}$ & $\begin{array}{l}\text { Reversion } \\
\text { index }\end{array}$ & $\begin{array}{l}\text { Other } \\
\text { properties }\end{array}$ \\
\hline $\begin{array}{c}49 \\
66 \\
78 \\
81 \\
85 \\
85 \\
87 \\
91 \\
92 \\
93 \\
160 \\
178 \\
194 \\
202 \\
203 \\
210 \\
211 \\
212 \\
214 \\
216 \\
218 \\
219 \\
220 \\
221 \\
223 \\
228 \\
231 \\
238 \\
239 \\
300 \\
301 \\
302 \\
305 \\
307 \\
311 \\
315 \\
317 \\
320 \\
323 \\
324 \\
330 \\
333 \\
335 \\
340 \\
342 \\
345 \\
347 \\
350 \\
363 \\
364 \\
369 \\
380 \\
382 \\
393 \\
394 \\
395 \\
401 \\
402 \\
406 \\
\\
408 \\
411\end{array}$ & $\begin{array}{l} \\
\\
\text { ser } \\
\text { ara7 } \\
\text { arag } \\
\text { arag } \\
\text { ara9 } \\
\text { arag } \\
\text { ara9 } \\
\text { arag } \\
\text { arag } \\
\text { arag } \\
\text { arag } \\
\text { arag } \\
\text { arag } \\
\text { arag } \\
\text { arag } \\
\\
\\
\\
\text { arag } \\
\text { arag } \\
\text { arag } \\
\text { arag } \\
\text { arag } \\
\text { arag } \\
\text { arag } \\
\text { arag } \\
\text { arag } \\
\text { arag } \\
\text { ara9 } \\
\text { ara9 } \\
\text { arag } \\
\text { arag }\end{array}$ & 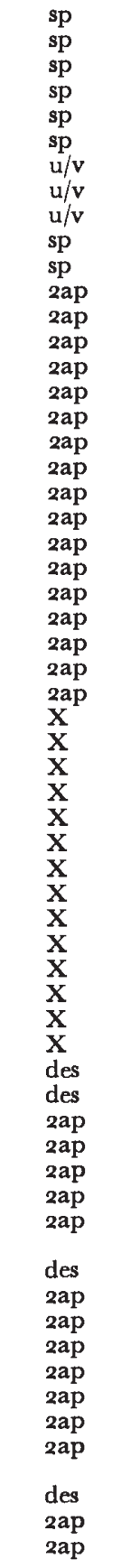 & 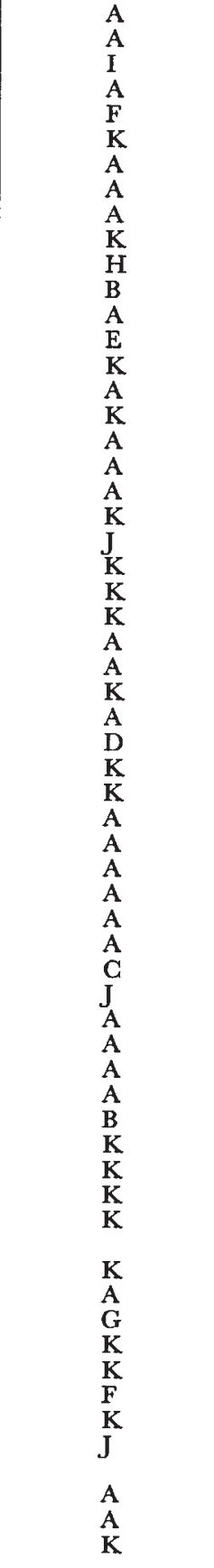 & $\begin{array}{c}+ \\
+ \\
++ \\
++ \\
++ \\
+ \\
+ \\
+ \\
++ \\
+ \\
+ \\
++ \\
+ \\
++ \\
+ \\
+ \\
+ \\
+ \\
+ \\
0 \\
+ \\
+ \\
+ \\
+ \\
+ \\
++ \\
++ \\
+++ \\
+ \\
+ \\
+ \\
+ \\
+ \\
+ \\
+ \\
+ \\
+ \\
+ \\
+ \\
+ \\
+ \\
+ \\
++ \\
++ \\
+ \\
+ \\
+ \\
+ \\
+ \\
+ \\
+ \\
+ \\
+ \\
+ \\
+ \\
+ \\
+ \\
+\end{array}$ & hs \\
\hline
\end{tabular}


TABLE I-(Continued)

\begin{tabular}{|c|c|c|c|c|c|}
\hline \multicolumn{6}{|c|}{$m e t C$} \\
\hline Mutant & $\begin{array}{l}\text { Other } \\
\text { markers }\end{array}$ & $\begin{array}{l}\text { Mode of } \\
\text { origin }\end{array}$ & $\begin{array}{l}\text { Complementation } \\
\text { group }\end{array}$ & $\begin{array}{l}\text { Reversion } \\
\text { index }\end{array}$ & $\begin{array}{l}\text { Other } \\
\text { properties }\end{array}$ \\
\hline $\begin{array}{c}30 \\
32 \\
35 \\
37 \\
50 \\
52 \\
56 \\
58 \\
65 \\
71 \\
79 \\
86 \\
88 \\
103 \\
104 \\
125 \\
193 \\
195 \\
233 \\
251 \\
354 \\
356 \\
359 \\
360 \\
372 \\
373 \\
374 \\
376 \\
377 \\
378 \\
379 \\
386 \\
399 \\
409 \\
415 \\
415 \\
417\end{array}$ & $\begin{array}{l}\text { arag } \\
\text { ara9 } \\
\text { arag } \\
\text { arag } \\
\\
\text { cysdl } 519 \\
\text { cysdl } 519 \\
\text { cysdl } 519 \\
\text { cysdl } 519 \\
\text { cysdl } 519 \\
\text { cysdl } 519 \\
\text { cysdl } 519\end{array}$ & $\begin{array}{l}\text { sp } \\
\text { sp } \\
\text { sp } \\
\text { sp } \\
\text { sp } \\
\text { sp } \\
\text { sp } \\
\text { sp } \\
\text { sp } \\
\text { sp } \\
\text { sp } \\
\text { sp } \\
\text { sp } \\
\text { sp } \\
\text { sp } \\
\text { sp } \\
2 a p \\
2 a p \\
2 a p \\
2 a p \\
2 a p \\
2 a p \\
2 a p \\
2 a p \\
2 a p \\
2 a p \\
2 a p \\
2 a p \\
2 a p \\
2 a p \\
2 a p \\
2 a p \\
2 a p \\
2 a p \\
2 a p \\
2 a p \\
2 a p\end{array}$ & $\begin{array}{l}\text { A } \\
\text { A } \\
\text { A } \\
\text { F } \\
\text { A } \\
\text { B } \\
\text { A } \\
\text { A } \\
\text { A } \\
\text { A } \\
\text { A } \\
\text { A } \\
\text { A } \\
\text { A } \\
\text { E } \\
\text { A } \\
\text { A } \\
\text { F } \\
\text { C } \\
\text { C } \\
\text { A } \\
\text { A } \\
\text { A } \\
\text { A } \\
\text { A } \\
\text { A } \\
\text { A } \\
\text { A } \\
\text { A } \\
\text { A } \\
\text { G } \\
\text { A } \\
\text { A } \\
\text { D } \\
\text { A }\end{array}$ & $\begin{array}{c}+ \\
++ \\
++ \\
++ \\
+ \\
++ \\
++ \\
+ \\
+ \\
++ \\
+ \\
+ \\
+ \\
++ \\
+ \\
+ \\
+ \\
++ \\
+ \\
+ \\
++ \\
++ \\
++ \\
++ \\
+ \\
+++ \\
+++ \\
+ \\
+ \\
+ \\
+ \\
++ \\
++ \\
++\end{array}$ & $\begin{array}{l}\text { hs } \\
\text { lys } \\
\text { hs }\end{array}$ \\
\hline \multicolumn{6}{|c|}{$m e t E$} \\
\hline Mutant & $\begin{array}{l}\text { Other } \\
\text { markers }\end{array}$ & $\begin{array}{l}\text { Mode of } \\
\text { origin }\end{array}$ & $\begin{array}{c}\text { Complementation } \\
\text { group }\end{array}$ & $\begin{array}{l}\text { Reversion } \\
\text { index }\end{array}$ & $\begin{array}{l}\text { Other } \\
\text { properties }\end{array}$ \\
\hline $\begin{array}{r}2 \\
47 \\
51 \\
60 \\
61 \\
68 \\
70 \\
80 \\
82 \\
84 \\
196 \\
197 \\
204 \\
205 \\
206 \\
217 \\
225\end{array}$ & $\begin{array}{l}\text { ara9 } \\
\text { ara9 } \\
\text { ara9 } \\
\text { ara9 } \\
\text { ara9 } \\
\text { ara9 }\end{array}$ & $\begin{array}{l}\text { u/v } \\
\text { sp } \\
\text { sp } \\
\text { sp } \\
\text { sp } \\
\text { sp } \\
\text { sp } \\
\text { sp } \\
\text { sp } \\
\text { sp } \\
2 a p \\
2 a p \\
2 a p \\
2 a p \\
2 a p \\
2 a p \\
2 a p\end{array}$ & $\begin{array}{l}\text { I } \\
\text { I } \\
\text { I } \\
\text { I } \\
\text { I } \\
\text { I } \\
\text { I } \\
\text { I } \\
\text { I } \\
\text { I } \\
\text { I } \\
\text { II } \\
\text { I } \\
\text { I } \\
\text { I } \\
\text { I } \\
\text { I }\end{array}$ & $\begin{array}{c}+ \\
0 \\
++ \\
+++ \\
+ \\
++ \\
++ \\
+ \\
+ \\
++ \\
++ \\
+++ \\
+ \\
+ \\
+ \\
+ \\
++\end{array}$ & $\mathrm{dl}$ \\
\hline
\end{tabular}


TABLE I-(Continued)

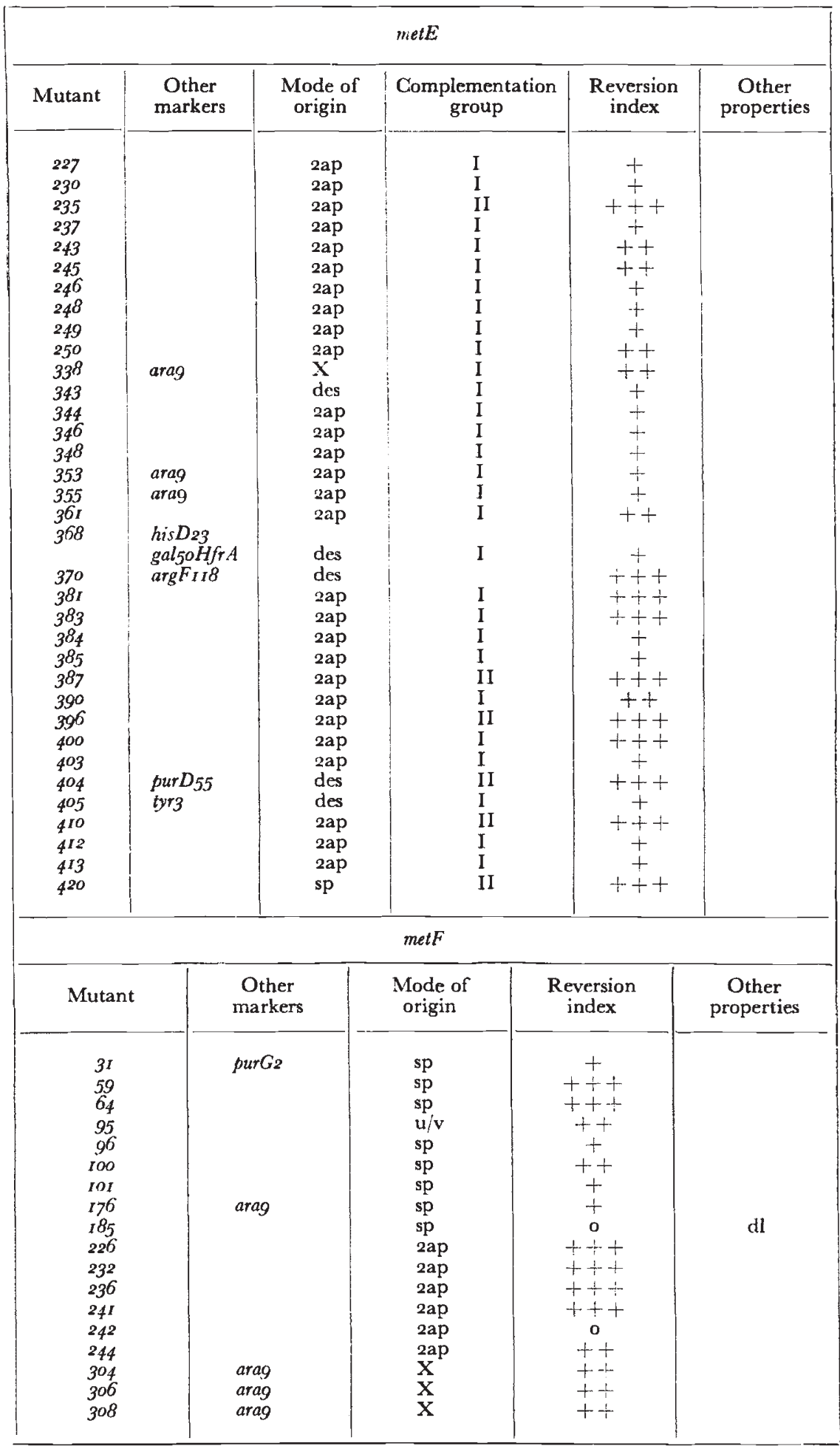


TABLE $:-$ (Continued)

\begin{tabular}{|c|c|c|c|c|}
\hline \multicolumn{5}{|c|}{ metF } \\
\hline Mutant & $\begin{array}{l}\text { Other } \\
\text { markers }\end{array}$ & $\begin{array}{c}\text { Mode of } \\
\text { origin }\end{array}$ & $\begin{array}{l}\text { Reversion } \\
\text { index }\end{array}$ & $\begin{array}{c}\text { Other } \\
\text { properties }\end{array}$ \\
\hline $\begin{array}{l}310 \\
318 \\
375 \\
392 \\
397 \\
4^{18} \\
4^{22}\end{array}$ & $\begin{array}{l}\text { arag } \\
\text { ara9 } \\
\text { cysdl } 5 \text { I9 }\end{array}$ & $\begin{array}{l}X \\
X \\
2 a p \\
2 a p \\
\text { 2ap } \\
2 a p \\
\text { sp }\end{array}$ & $\begin{array}{c}t \\
+ \\
+++ \\
+++ \\
++t \\
+++ \\
+\end{array}$ & \\
\hline \multicolumn{5}{|c|}{ metG } \\
\hline Mutant & $\begin{array}{c}\text { Other } \\
\text { markers }\end{array}$ & $\begin{array}{l}\text { Mode of } \\
\text { origin }\end{array}$ & $\begin{array}{l}\text { Reversion } \\
\text { index }\end{array}$ & $\begin{array}{c}\text { Other } \\
\text { properties }\end{array}$ \\
\hline $\begin{array}{l}319 \\
371 \\
419 \\
421\end{array}$ & $\begin{array}{l}\operatorname{arag}_{\text {cysdll }} \\
\text { s. }_{5}\end{array}$ & $\begin{array}{l}X \\
2 a p \\
\text { sp } \\
\text { sp }\end{array}$ & $\begin{array}{l}+++ \\
+++ \\
+++ \\
+++\end{array}$ & \\
\hline \multicolumn{5}{|c|}{ Non-transducible } \\
\hline Mutant & $\begin{array}{l}\text { Other } \\
\text { markers }\end{array}$ & $\begin{array}{c}\text { Mode of } \\
\text { origin }\end{array}$ & $\begin{array}{l}\text { Reversion } \\
\text { index }\end{array}$ & $\begin{array}{c}\text { Other } \\
\text { properties }\end{array}$ \\
\hline $\begin{array}{r}97 \\
102 \\
299 \\
312 \\
314 \\
316 \\
325 \\
3^{27} \\
334 \\
336 \\
.337\end{array}$ & $\begin{array}{l}\text { ara9 } \\
\text { ara9 } \\
\text { ara9 } \\
\text { arag } \\
\text { ara9 } \\
\text { ara9 } \\
\text { ara9 } \\
\text { ara9 } \\
\text { ara9 }\end{array}$ & $\begin{array}{l}\text { sp } \\
\text { sp } \\
\text { X } \\
\text { X } \\
\text { X } \\
\text { X } \\
\text { X } \\
\text { X } \\
\text { X } \\
\text { X } \\
\text { X }\end{array}$ & $\begin{array}{c}+ \\
+ \\
++ \\
+ \\
+ \\
+ \\
+ \\
+ \\
+ \\
0 \\
+\end{array}$ & hs \\
\hline
\end{tabular}

Other nutritional requirements, $\arg =$ arginine; $\quad$ cys $=$ cysteine; $\quad$ his $=$ histidine ; pur $=$ purine; try $=$ tryptophan; $t y r=$ tyrosine.

Inability to ferment sugars, $a r a=$ arabinose; $g a l=$ galactose.

$H f r=$ high frequency recombination male strain.

Mode of origin, 2 ap = induction with 2 aminopurine; des $=$ induction with diethyl sulphate; $\mathrm{sp}=$ spontaneous; $\mathrm{u} / \mathrm{v}=$ induction with ultra violet light; $\mathrm{X}=$ induction with X-rays.

Reversion index (average number of revertant colonies per $2-3 \times 10^{9}$ bacteria plated on MA medium) $0=$ none; $t=$ above $0-5 ;+t=5-50 ;+t+=$ above 50 .

Other properties, $\mathrm{dl}=$ deletion; hs = heat sensitivity; lys $=$ lysogenic.

All mutants were obtained from Dr M. Demerec, Department of Biology, Brookhaven National Laboratory, Upton, Long Island, New York, U.S.A., except metF 422 (SL ${ }_{5}^{82}$ ) supplied by Professor B. A. D. Stocker, Lister Institute of Preventive Medicine, Chelsea Bridge Road, London, S.W.I, and metE420, met $G_{4} I 9$ and met $G_{42 I}$ which were isolated in this department. 
known met genes $A, B, C, E$ and $F$ (Smith, 1961). One hundred and twenty-four of these mutants responded to homocysteine (including 28 which were leaky at $37^{\circ} \mathrm{C}_{\text {. }}$ ), 47 to vitamin $\mathrm{B}_{12}$ and 28 to methionine alone. The results of the transduction tests using the modified rapid technique indicated that those responding to homocysteine comprised $30 \mathrm{met} A, 5^{8} \mathrm{met} B$ and $28 \mathrm{met} C$ (leaky) mutants and that 46 of the 47 that responded to $\mathrm{B} 12$ were $m e t E$ mutants. Twenty-two of those responding to methionine only were $m e t F$ mutants.

Thus the gene deficiencies of 184 of the 199 new mutants were clearly identified. Of the remaining i 5 mutants i c could not be used in transduction experiments as they were not transducted by phage

TABLE 2

Met mutants arranged according to their mode of origin (from Table I)

\begin{tabular}{|c|c|c|c|c|c|c|c|c|}
\hline \multirow{2}{*}{\multicolumn{2}{|c|}{ Mode of origin of mutants }} & \multicolumn{6}{|c|}{ Numbers of mutants of each gene } & \multirow{2}{*}{ Totals } \\
\hline & & metA & $\operatorname{met} B$ & $\operatorname{met} C$ & $\operatorname{met} E$ & $\operatorname{met} F$ & $\operatorname{met} G$ & \\
\hline \multirow{2}{*}{\multicolumn{2}{|c|}{ Spontaneous . }} & I9 & 18 & I 6 & Io & 9 & 2 & 74 \\
\hline & & 5 & 4 & 0 & I & I & o & II \\
\hline \multirow{2}{*}{ Induced } & X-ray & 9 & 14 & o & I & 5 & I & 30 \\
\hline & $\begin{array}{l}\text { 2-aminopurine } \\
\text { diethyl sulphate. }\end{array}$ & $\begin{aligned} \text { II } \\
0\end{aligned}$ & $\begin{array}{r}31 \\
4\end{array}$ & $\begin{array}{r}21 \\
0\end{array}$ & $\begin{array}{r}35 \\
5\end{array}$ & $\begin{array}{r}\text { ro } \\
\text { o }\end{array}$ & $\begin{array}{l}\mathrm{I} \\
\mathbf{0}\end{array}$ & $\begin{array}{r}109 \\
9\end{array}$ \\
\hline Totals & . & 44 & $7^{1}$ & 37 & $5^{2}$ & 25 & 4 & 233 \\
\hline
\end{tabular}

propagated on any met mutant used or wild type and phage could not be propagated on them. The reasons for this are largely unknown. Only one of these mutants (metro2) appeared to be lysogenic using wild type $S$. typhimurium as an indicator. The other 4 mutants were transduced at about the same frequency by met $A, B, C, E$ and $F$ phage suspensions. Transduction between them was either not detected or occurred at a much lower frequency. Also, they were all slightly leaky at $37^{\circ} \mathrm{G}$., showed high reversion frequencies and, as recipients in transduction yielded Io- Ioo times more recombinants with wild type donors than other met mutants. They were considered to be mutants of a new gene designated $m e t G$.

\section{(ii) The relationship between mode of origin and site of methionine mutation}

If the methionine mutants whose gene deficiencies can be identified are arranged according to their mode of origin (table 2) it is seen that no $m e t C$ and very few met $E$ mutants appear to be induced by X-rays (and $\mathrm{u} / \mathrm{v}$ light, although the numbers are low) and the incidence of met $E$ mutants and, to lesser extent, met $B$ mutants is greatly increased if 2-aminopurine is used as a mutagen. Nitrous acid would appear to have an affect similar to 2-aminopurine at least with respect to metE mutants, because recent investigation revealed 20 of them among 28 
met mutants isolated after induction with this mutagen. (Miss F. Pettit, personal communication.)

Reconstruction experiments to determine the effect of penicillin enrichment on the survival of small numbers of met $A, B, C, E$ and $F$ bacteria in mixed cultures with large numbers of $\mathrm{X}$-irradiated wild type bacteria revealed no significant differential loss of viability between the different met mutants (M. Stern, personal communication). This would suggest that the absence of met $C$ mutants and low numbers of met $E$ mutants following $\mathrm{X}$-irradiation was not a penicillin enrichment artefact.

\section{(iii) The pathway of methionine synthesis}

There was previously some doubt whether cystathionine was an intermediate in methionine synthesis in S. typhimurium (Smith, 196r). The preparation of cystathionine used stimulated an equally slow growth response of met $A, B$ and $C$ mutants. As the medium supplemented with the cystathionine used was found to contain small quantities of homocysteine after incubation, this growth response was considered to be insignificant. However, DL-allo cystathionine (Calbiochem) elicited a clear and rapid growth response from met $A$ and $B$ mutants, a much slower response from met $C$ mutants, which are leaky anyway, and no response at all from met $E, F$ or $G$ mutants. The cystathionine growth responses of the met $A$ and $B$ mutants were still slower than that of these and the met $C$ mutants to either homocysteine or methionine suggesting a deficiency in permeability for cystathionine. These results were confirmed in quantitative experiments in which the generation times and lag period of representative mutants of all 6 met genes were measured in the liquid glucose-lactate salts minimal medium of Szulmajster and Woods ( 1960 ) supplemented with either cystathionine, homocysteine or methionine (Dr M. Foster, personal communication). It was therefore concluded that cystathionine was an intermediate in methionine synthesis in this organism and that the met $A$ and $B$ genes controlled biosynthetic steps before this substance and the met $C$ gene a step between it and homocysteine.

The enzymic deficiencies of representative mutants of each of 5 of the met genes have been identified (fig. I). The met $A$ mutants lack homoserine $O$-transsuccinylase and are unable to convert homoserine and succinate to $O$-succinylhomoserine and met $B$ mutants, lacking cystathionine synthetase, cannot synthesise cystathionine from this intermediate and cysteine (Rowbury, $1964 a, b$ ) and so accumulate small quantities of $O$-succinylhomoserine (Rowbury, I964a). The met $C$ mutants lack cystathionase and are thus unable to convert cystathionine to homocysteine (Dr Rowbury, personal communication). The methylation of homocysteine to methionine can be achieved in two ways as in $E$. Coli (Guest, Friedman and Foster, 1962). One involves the direct transfer to homocysteine of the methyl group from 
D. A. SMITH AND J. D. GHILDS

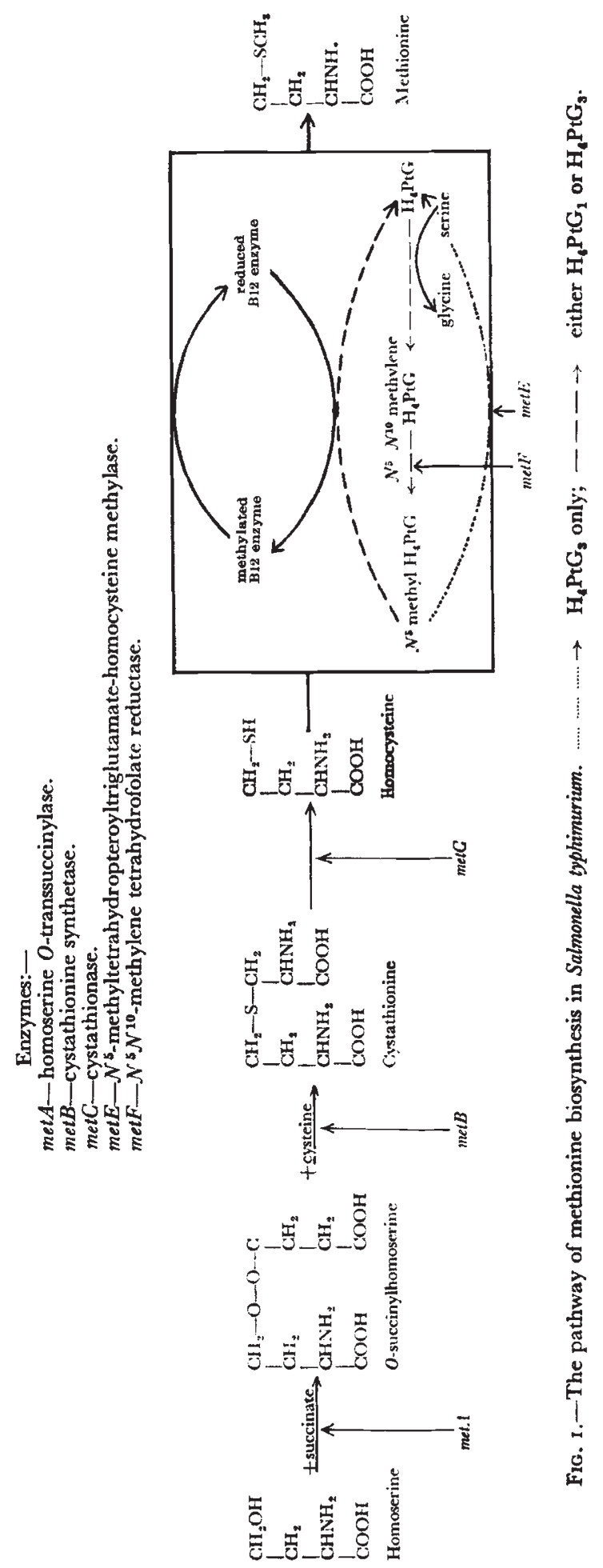


a methyl derivative of the folic acid cofactor tetrahydropteroyltriglutamate $\left(\mathcal{N}^{5}\right.$-methylH $\left.{ }_{4} \mathrm{PtG}_{3}\right)$ and the other an indirect transfer from the same substance or the monoglutamate form $\left(\mathcal{N}^{5}\right.$-methylH $\left.{ }_{4} \mathrm{PtG}_{1}\right)$ indirectly via an enzyme containing vitamin $\mathrm{BI}_{2}$. The metE mutants lack $\quad \mathcal{N}^{5}$-methyltetrahydropteroyltriglutamate-homocysteine transmethylase, and are unable to carry out the direct methylation. As the amount of vitmain BI 2 synthesised by $S$. typhimurium is inadequate for the indirect pathway to function, the methionine requirement of met $E$ mutants can be overcome by supplying vitamin $\mathrm{B} 12$ (Cauthen and Foster, unpublished). The intracellular supply of $\mathcal{N}^{5}$-methyl$\mathrm{H}_{4} \mathrm{PtG}_{1}$ or $\mathcal{N}^{5}$-methylH $\mathrm{PtG}_{4}$ is maintained by the methylation of $\mathrm{H}_{4} \mathrm{PtG}_{1}$ or $\mathrm{H}_{4} \mathrm{PtG}_{3}$ in two stages. Firstly, $\mathcal{N}^{5} \mathcal{N}^{10}$-methylene $\mathrm{H}_{4} \mathrm{PtG}_{1}$ or $\mathcal{N}^{5} \mathcal{N}^{10}$-methylene $\mathrm{H}_{4} \mathrm{PtG}_{3}$ is formed by the transfer of the hydroxymethyl group from serine by serine hydroxymethyl transferase (glycine being formed in the reaction) and secondly, these compounds are reduced to either $\mathcal{N}^{5}$-methylH ${ }_{4} \mathrm{PtG}_{1}$ or $\mathcal{N}^{5}$-methylH $\mathrm{H}_{4} \mathrm{PtG}_{3}$ (Guest, et al., I 962). The met $F$ mutants are unable to carry our this reduction as they are deficient in $\mathcal{N}^{5} \mathcal{N}^{10}$-methylenetetrahydrofolate reductase (Foster, unpublished).

Syntrophism tests between $\operatorname{met} G$ mutants and representative met $A$, $B, C, E$ and $F$ mutants using the replica plating method (Smith, I96I) revealed cross feeding only between $\operatorname{met} G$ and $C$ mutants, met $C$ organ isms predominating in the areas of syntrophic growth. However, as met $C$ mutants are leaky at $37^{\circ}$ and leaky methionine mutants respond to much lower levels of utilisable growth factors than non-leaky mutants (Smith, 196I), this cross feeding reaction was considered to be of doubtful significance. Subsequent studies (Foster, personal communication) showed that met $G$ mutants do not appear to have a specific enzyme deficiency. They exhibit very low met $C, E$ and $F$ enzyme activity and also probably much reduced $m e t A$ and $B$ activity.

\section{(iii) The fine structure of each met gene}

The fine structure of the met genes was studied by determining the intragenic recombination and complementation behaviour of each mutant of each gene using the rapid transduction technique exclusively. At the same time the residual growth characteristics and reversion frequency of each mutant were also observed. A reversion index based on the average number of revertants per $2-3 \times 10^{9}$ bacteria plated on the selective medium used in each experiment is recorded in table I. The possible heat sensitivity of each mutant was tested separately.

In complete and abortive transduction experiments the controls comprised homologous crosses, crosses between each donor and a nonmethionine recipient and between each recipient and a wild type donor. Mutants were considered not to recombine only if the original cross, its reciprocal and repetition of the cross in both directions in 
triplicate failed to yield recombinants. Complementation between mutants was considered to occur only if the first observation of abortive transduction could be detected on repeating the cross and, in most cases, in its reciprocal. When mutants appeared not to revert, $\mathrm{O} \cdot \mathrm{I} \mathrm{ml}$. quantities of $\times$ Io concentrated washed overnight cultures were spread on to each of at least 5 appropriately supplemented MA medium plates and incubated for a minimum of two days. Colonies appearing after this time were picked and streaked on to similar MA medium to determine whether they possessed wild type growth characteristics. If a mutant did not revert and also failed to recombine with mutants which themselves recombined with each other, it was considered to be a multisite (deletion) mutant. If mutants showed the same recombination and complementation pattern in crosses, failed to recombine with each other and possessed similar residual growth characteristics and reversion frequencies, their sites of mutation were considered to be identical.

The results of these experiments will be considered gene by gene:

I. metA. Forty-two of the 44 metA mutants were used in intragenic transduction experiments. The use of metAro was impossible because it yielded very low numbers of recombinants even in intergenic crosses and metAr 8 could not be used because it appeared to be lysogenic. All possible crosses were carried out between 38 (met $A 7-339$ inclusive) of these 42 mutants: those involving the remaining four (metA35I-4I4 inclusive) were on a more restricted scale.

Five mutants $m e t A 7,22,15,43$ and 309 behaved as deletions. The failure of $m e t A_{43}$ to recombine with any other metA mutant indicated that it was likely to be a deletion for the whole gene. Although $m e t A 7$ failed to recombine with any of the other deletions, it recombined with one point mutant (metA229) which failed to recombine with metA 43 so the extent of its deleted region was considered to be less than that of metA43. Also metAr5 recombined with both metA22 and 309 but these two mutants did not recombine with each other. The occurrence of point mutants which recombined with either metA22 or 309 in addition to those recombining with neither suggested that these two deletions did not overlap completely.

An unambiguous linear deletion map of the metA gene in which overlapping lines indicate failure to recombine, cannot be constructed but one of the 8 possible maps appears in fig. 2. In it 8 regions are defined but there are 7 other possible orders for these regions. They are: abcfedgh, adefcbgh, afedcbgh, habcdefg, habcfedg, hadefcbg and hafedcbg. The reality of these regions whatever their order is supported by considering presence or absence of recombination between metA point mutants and the deletions. Twenty-one of these 37 point mutants could be assigned to specific regions; 5 to region $b$, one to d, 5 to $\mathrm{e}, 9$ to $\mathrm{F}$ and one to $\mathrm{h}$. The remaining $\mathrm{I} 6$ mutants showed patterns of recombination characteristic of regions a, c or $\mathrm{g}$. Also failure of recombination between point mutants was mainly confined to those 
whose sites of mutation were in the same region or the adjacent regions $\mathrm{d}$, e and $\mathrm{f}$.

Observations of the reversion frequencies and residual growth characteristics of mutants failing to recombine indicated that the sites of mutation of each of the pairs metA2I and $388,9^{8}$ and 99,201 and 414 and 247 and 253 were probably identical. No abortive transduction (complementation) was detected between any of the metA mutants. Four of them, metArg, 53, $9^{8}$ and 99 were heat sensitive (table I).

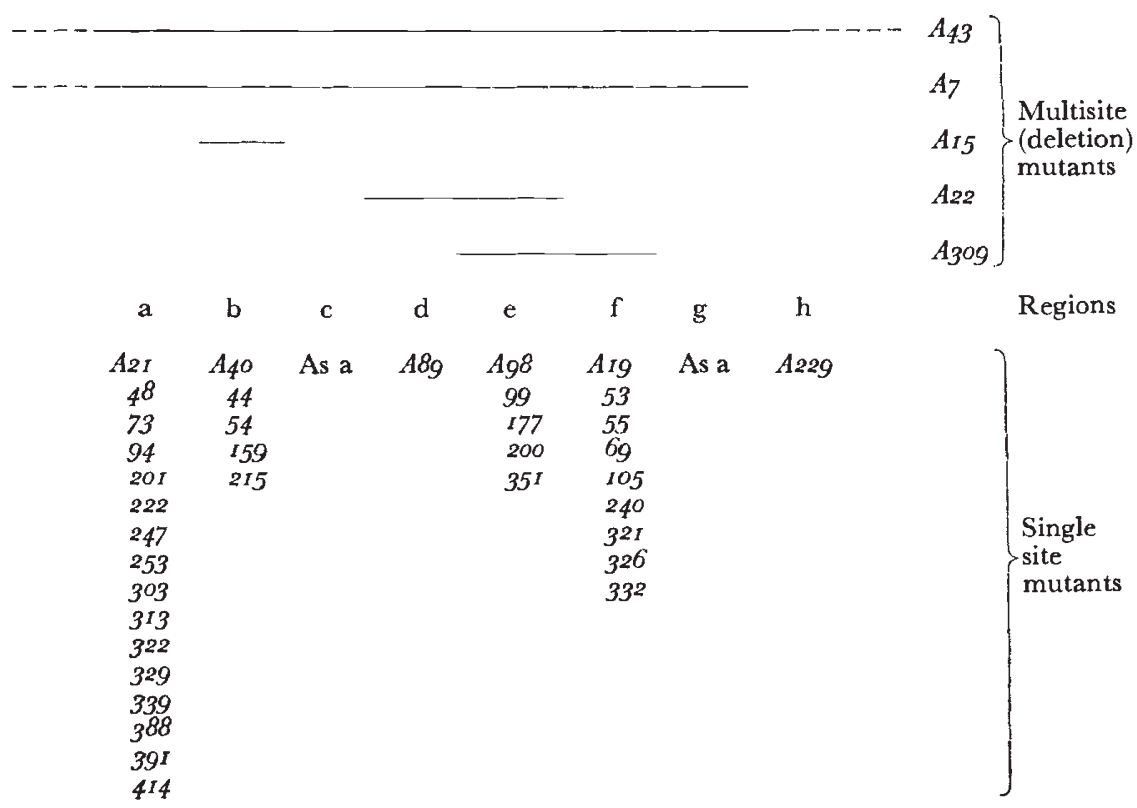

Fig. 2.-A deletion map of the $m e t A$ gene.

2. met $B$. All of the 70 metB mutants were used in intragenic transduction experiments although results obtained with 6 of them (metB8I, 194, 239, 345, 408 and 411 ) were rather unreliable either because of their high reversion frequencies or heavy residual growth characteristics or both.

One mutant $\left(m_{t} B_{3} 6\right)$ was completely stable and failed to recombine with any other met $B$ mutant, thus lending support to the previous suggestion that it was a deletion mutant (Smith, I96I). It is likely to be a deletion for the whole metB gene. Most other mutants recombined with each other. Consideration of the similarities of reversion frequency and residual growth characteristics of those that did not, indicated that the three mutants $\operatorname{met}_{1} 6, I_{1}$ and 93 , and each of the three pairs met $B_{39}$ and 324,92 and 340 , and 393 and 394 were identical site mutants.

Some intragenic abortive transduction occurred between met $B$ mutants. Although the numbers and size of the minute colonies was 
not necessarily the same in each cross, a complex pattern of complementation was apparent and is summarised in fig. 3. The mutants fell into I 2 groups. One group (A) comprised 3 I mutants which failed to complement any other metB mutant. The other 39 mutants could be divided into I I groups (B-L) on the basis of their patterns of complementation. Ten of these groups comprised one to three mutants and the other (K) 22 mutants (see also table I). A complementation matrix was constructed which could be expressed as an unambiguous linear map in which overlapping lines indicate failure to complement (Catcheside, I960).

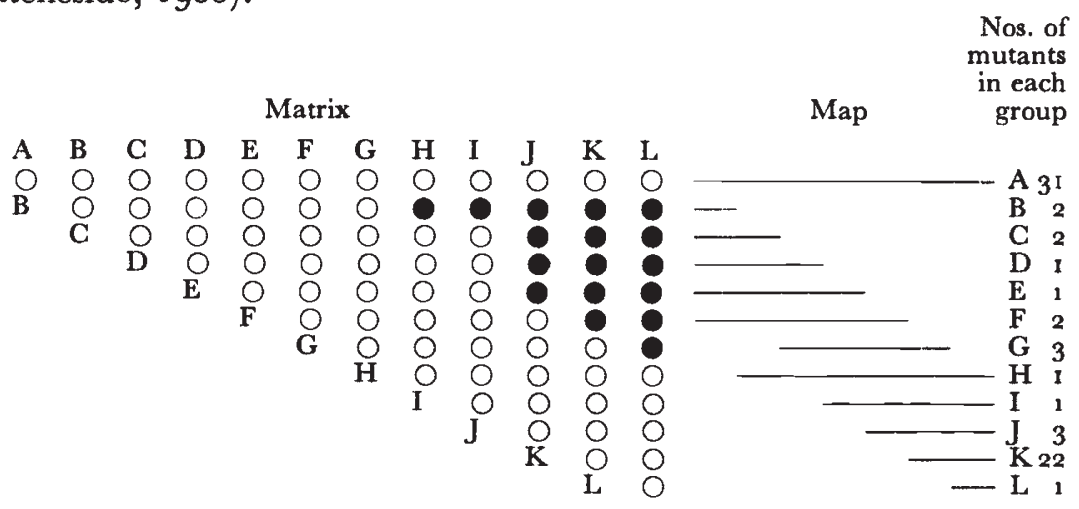

FIG. 3.-Complementation between metB mutants. $O=$ no complementation; $O=$ poor complementation; $=$ complementation. Overlapping lines in the map indicate failure to complement (after Catcheside, i 960 ).

Two mutants, metBIg4 and 345 , the only representatives of complementation group $B$, were heat sensitive. In addition, these were the only metB mutants to exhibit mucoid colony morphology when growing slowly at $20^{\circ}$ on MA medium. This was found to be an indirect result of the mutation to methionine requirement in these two mutants probably related to an intracellular imbalance of nitrogen and polysaccharide metabolism during their slow growth on MA medium (Childs, 1964).

3. metC. Mutants of this gene were difficult to study as all were leaky at $37^{\circ}$. In using the spot transduction technique incubation for three days at $25^{\circ}$, where the strains involved were not heat sensitive, facilitated much easier detection of complete and abortive transduction.

Only one of the $37 \mathrm{metC}$ mutants could not be used. This was ${ }^{m e t} C_{37} 8$ whose residual growth on MA medium was too great to permit the detection of recombinants when it was used as a recipient. All of the remaining 36 mutants were crossed with each other. Three (metC $50,5^{8}$ and 386$)$ had some of the characteristics of deletions in that they failed to recombine with other mutants which themselves recombined. However, each of these strains reverted at a very low frequency of $c .10^{-10}$ so that the construction of a deletion map was 
not attempted. Three mutants, met $C_{30}, 379$ and possibly 360 , were identical site mutants.

Observations of intragenic abortive transduction suggested that each of 35 of the met $C$ mutants could be assigned to one of 7 complementation groups (fig. 4 and table I). One group (A) comprised 27 mutants which failed to complement any metC mutants. The patterns of abortive transduction between the remaining 8 mutants permitted their arrangement into 6 further groups (B-G). A matrix expressing these data and the unambiguous linear map constructed from it appear in fig. 4 .

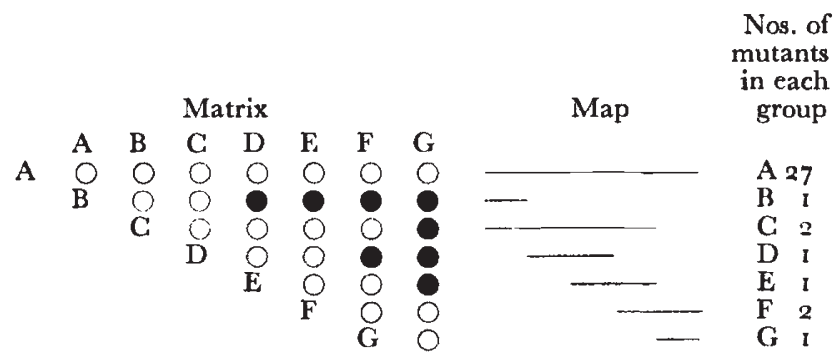

FIG. 4.-Complementation between met $C$ mutants. $O=$ no complementation; $O=$ poor complementation; $=$ complementation. Overlapping lines in the map indicate failure to complement (after Catcheside, I96o).

Four metC mutants $(30,65,360$ and 379$)$ were heat sensitive. All were in complementation group $\mathrm{A}$ and two or three of them were probably identical site mutants.

4. metE. The transduction experiments with the 52 mutants of this gene were carried out in two stages. The first involved making all possible crosses between the 28 mutants from metE2-338 inclusive and results indicated that none of these mutants were deletions although met $E_{47}$ failed to revert. Abortive transduction was detected in some crosses and each mutant could be assigned to one of two groups (I or II). All 26 mutants of group I complemented both the group II mutants (metEr.97 and 23.5) and vice versa. No complementation occurred between mutants of the same group.

In the second stage the remaining 24 mutants (metE343-420 inclusive) were each transduced with two group I mutants (met $E_{47}$ and 204) and the two group II mutants. None of these 24 mutants possessed the reversion and transduction characteristics of deletions. Eighteen fell into complementation group I, 5 into group II and one (met $E_{370}$ ) could not clearly be assigned to a complementation group because of difficulty in detecting minute colonies using it as a recipient, even in crosses in which wild type was donor. Thus a total of 44 met $E$ mutants fell into complementation group I and 7 into group II (table I) giving an overall complementation pattern quite different from that of either the met $B$ or $m e t C$ mutants.

It was interesting to note that the frequency of complete transduction between mutants of different complementation groups was often as much as four times that between mutants of the same group. Also 
the average reversion frequency from group II mutants was at least Io times greater than that for group I mutants.

All metE mutants appeared to arise from mutation at different sites and none was heat sensitive.

5. $m e t F$. The results of all possible crosses between the 25 metF mutants showed that one mutant, (metF $\left.F_{1} 85\right)$ was a deletion and seven mutants failed to recombine with it $\left(\mathrm{metF}_{4}, 100,232,244,304,306\right.$ and 422 ). Only metF IOI and 242 appeared to be identical site mutants, although the high reversion frequencies of $\mathrm{metF}_{59}, 64,226,241,392,397$ and $4^{I} 8$ made recombination between these mutants difficult to detect. No intragenic abortive transduction was observed and no $m e t F$ mutant was heat sensitive.

6. $m e t G$. When used as recipients in transduction met $G$ mutants all yielded recombinants at a frequency ro-I oo times that obtained with mutants of other met genes in both inter and intragenic crosses. This necessitated the use of unconcentrated recipient broth cultures of them in transduction experiments using the rapid technique. However, their leakiness and high reversion frequency still made scoring of recombinant colonies and observation of minute (abortive transduction) colonies difficult so that the results obtained with met $G$ mutants may be unreliable.

In intragenic transduction experiments involving all possible crosses in both directions $m e t G_{41} 9$ and $42 I$ behaved similarly. They both recombined with and complemented met $G_{31} g$ and $37 I$ although neither interaction occurred between them. On the other hand recombination and complementation was detected between met $G_{319}$ and $37 I$. It was concluded that met $G_{419}$ and $42 I$ were identical-site mutants and that it was likely that the complementation pattern of the $m e t G$ was complex. No $m e t G$ mutant was heat sensitive.

\section{(iv) Attempted detection of linkage between metG and other met genes}

If bacterial genes are very closely linked they may be co-transduced. It was previously shown in donor phenotype selection experiments that of the five genes met $A, B, C, E$ and $F$ only met $B$ and $F$ were cotransducible (Smith, $196 \mathrm{I}$ ). These experiments were extended to see if the met $G$ gene was closely linked to the $m e t A, B, C$ or $E$ genes (the growth response pattern of $m e t F$ and $G$ mutants is the same thus precluding donor phenotype selection). All of at least 2000 recombinant colonies from each of the crosses between $\operatorname{met}_{3} G_{19}$ and met $A_{7}, B 66$ and $C_{30}$ plated on MAthomocysteine medium and between the same strain and metE2 plated on $M A+$ vitamin $B_{12}$ medium were wild type. This indicated no co-transduction of the $m e t G$ and either the met $A, B, C$ or $E$ genes.

\section{DISCUSSION}

(i) The genes and enzymes concerned with methionine biosynthesis

The numbers of methionine mutants of Salmonella typhimurium studied has been expanded from 46 (Smith, I96I) to 243. Results 
obtained support the existence of the 5 methionine genes originally identified (met $A, B, C, E$ and $F$ ) and have revealed another $(\operatorname{met} G)$. Parallel work on the enzyme deficiencies of similar Escherichia coli mutants and representative $S$. typhimurium mutants (Rowbury, I964a, $b$; Rowbury and Woods, I964; Wijesundera and Woods, I962; Woods, Foster and Guest, I 965 ; Foster, personal communication) has permitted the firm establishment of the same pathway of methionine synthesis in these two organisms (fig. I). It was particularly satisfactory that work with the met $A, B$ and $C$ mutants of $S$. typhimurium supported the existence of $O$-succinylhomoserine as a precursor of cystathionine and that the enzyme deficiencies of the metE and $F$ mutants $\left(\mathcal{N}^{5}\right.$-methyltetrahydropteroyltriglutamate-homocysteine methylase and $\mathcal{N}^{5} \mathcal{N}^{10}$-methylene tetrahydrofolate reductase respectively) were compatible with the postulated two pathways of methylation of homocysteine. The recent isolation of mutants of $S$. typhimurium unable to methylate homocysteine indirectly via the enzyme containing vitamin $\mathrm{BI}_{2}$ lends further support to this postulate (Childs, unpublished). Because the met $A, B, C, E$ and $F$ mutants possess specific enzyme deficiencies it is likely that these genes are structural (Jacob and Monod, I96I). As met $G$ mutants do not possess a specific enzyme deficiency but show a low level of met $A, B, C, E$ and $F$ enzyme activity the function of the $\operatorname{met} G$ gene may be regulatory.

Results of the intragenic complementation tests between mutants of the five structural genes indicate something of the nature of their enzymes. The absence of complementation between mutants of the $m e t A$ and $F$ genes, suggests that homoserine $O$-transsuccinylase and $\mathcal{N}^{5} \mathcal{N}^{10}$-methylene tetrahydrofolate reductase are monomers. On the other hand, the complex complementation patterns of the met $B$ and $C$ genes, which can be expressed in the form of linear maps, suggest that cystathionine synthetase and cystathionase each comprise more than one identical polypeptide subunit (Fincham, 1962) and are perhaps multimers (Crick and Orgel, I964). As metE mutants can be assigned to either one of two complementation groups and the frequency of recombination between mutants of the different groups was higher than that between mutants of the same group, it is likely that the metE gene is composed of two functional units or cistrons (Benzer, I957) and that $\mathcal{N}^{5}$-methyltetrahydropteroyltriglutamatehomocysteine methylase comprises two different polypeptide subunits.

It has recently been found that metEI and EII mutants appear to be biochemically identical except that they have different growth characteristics in minimal medium supplemented with vitamin $B_{12}$ : metEI mutants commence growth immediately but metEII mutants exhibit a lag period of 4-5 hr. (Miss S. Cauthen, personal communication). This is difficult to explain because in the presence of adequate vitamin $\mathrm{B}_{\mathrm{I}} 2$ the indirect methylation of homocysteine by the unrelated B 2 enzyme (fig. I) should proceed quite normally if the direct pathway is non-functional whatever the reasons for the deficiency. 
Although the metA deletion map (fig. 2) did not permit the precise location of the metA point mutants, it was unfortunate that similar maps of the met $B$ and $C$ genes facilitating at least some comparison with their complementation maps (figs. 3 and 4 ) could not be constructed

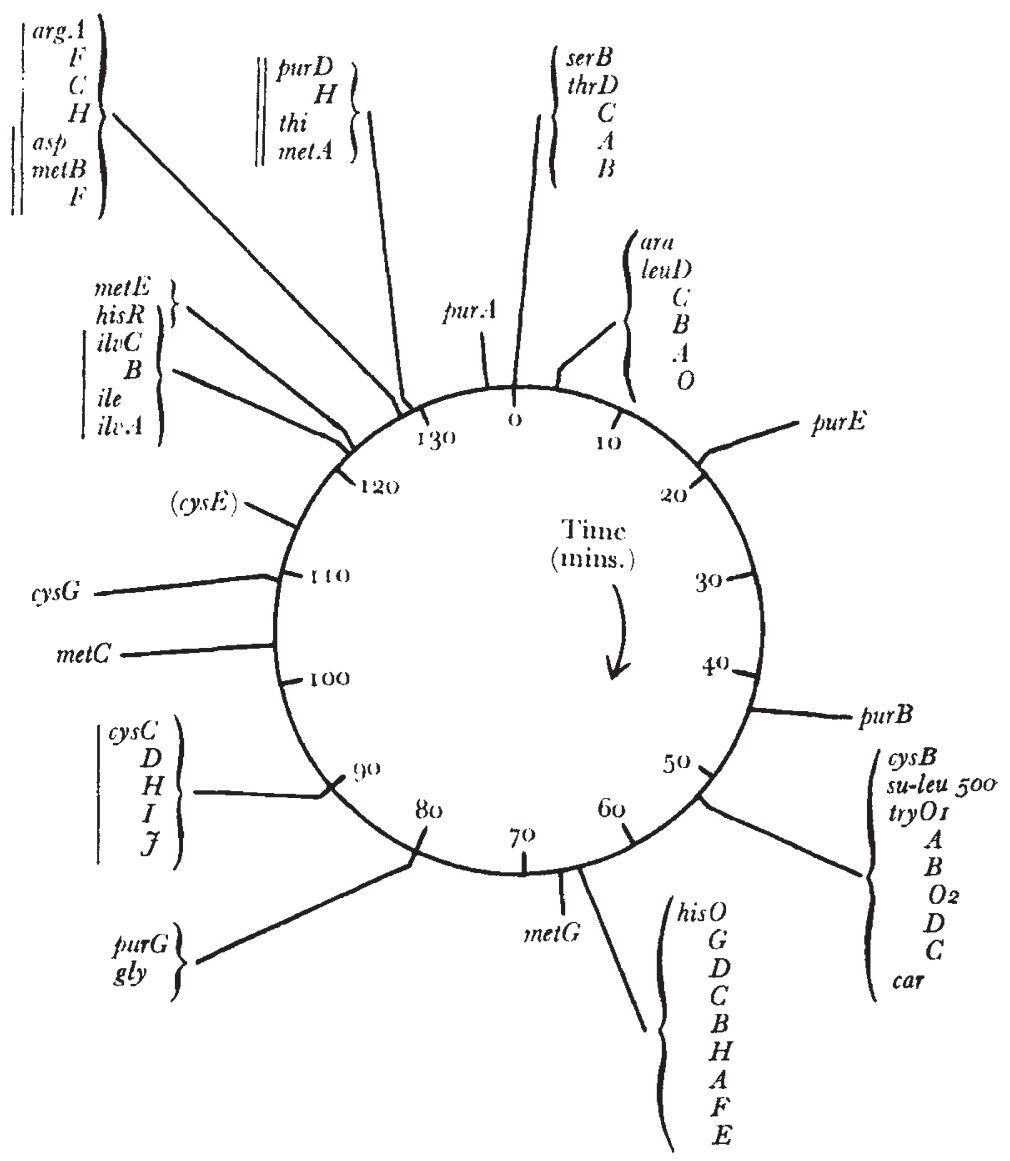

Fig. 5.-Part of the circular linkage map of Salmonella typhimurium. (After Sanderson and Demerec, 1965 ).

The time scale on the inside of the circle is based on the time of entry of the different genes during $H f r$ conjugation. $\}=$ transducing fragment; gene order and orientation known. $\beta=$ transducing fragment; gene order known, orientation unknown $\|\}=$ transducing fragment; gene order and orientation unknown. () approximate position.

The symbols are those used in table I with the following additions:-

I. nutritional requirements, asp = aspartate or glutamate; $g l y=$ glycine; ile $=$ isoleucine; $i l v=$ isoleucine-valine; leu = leucine; ser = serine or glycine; thi = thiamin; $t h r=$ threonine.

2. $c a r=$ carbohydrate utilisation.

3. su-leu5oo = suppressor of leu5oo.

(ii) Mutagen susceptibility of the met genes

As so little is known about the mechanism of X-ray induced mutation speculation on any special properties of the met $C$ and $E$ genes, which show equal insusceptibility to that mutagen (table 2), is impossible. It is unlikely that there is a common explanation for the 
absence of ultra-violet and X-ray induced mutants of the metC gene as the mechanism of induced mutation by non-ionising irradiation is probably different from that of ionising irradiation.

Concerning the relatively greater incidence of 2-aminopurine and nitrous acid induced mutations of the metE gene, Margolin ( 1963 ) also noted a similar effect in a study of ${ }_{15} 6$ leucine (leu) auxotrophs of $S$. typhimurium. Of the four leu structural genes I, II, III and IV (later labelled leuA, B, C and $D$-see fig. 5) the relative incidence of mutants of gene I was much greater following the use of 2-aminopurine, 5 -bromouracil and nitrous acid as mutagens compared with that using $\mathrm{X}$-rays or no mutagen. This could mean that $\mathrm{AT} \rightleftharpoons \mathrm{GC}$ transitions (Freese, 1959) occur more frequently in the metE and leuI genes than in other met and leu genes.

(iii) The location of the met genes on the linkoge map of Salmonella typhimurium

Part of the linkage map of $S$. typhimurium based on cotransduction and $H f r$ conjugation data (Sanderson and Demerec, I965) is reproduced in fig. 5. It can be seen that although the met $A, B, F$ and $E$ genes are located within an arc equivalent to about $\mathrm{I} / 2$ oth of the total map they could not be regarded as clustered in the way that the histidine (his), tryptophan (try), leucine (leu) and threonine (thr) genes are. Also the met $C$ and $G$ genes are located in quite different regions of the map. The met gene locations are therefore somewhat similar to those of the purine (pur) and cysteine (cys) genes in that some are co-transducible and others widely separated.

\section{(iv) The control of methionine biosynthesis}

Although the studies of the methionine mutants of S. typhimurium are in their early stages, some consideration of the likelihood of an operon model (Jacob and Monod, I961; Ames and Martin, 1964) for the mode of control of methionine biosynthesis in this organism is permissible:-

(1) Is there any suggestion that functionally related methionine structural genes are clustered together with a regulatory (operator) gene at one end of the cluster? Only met $B$ and $F$ are cotransducible, $m e t A, C$ and $E$ are quite separate. Operator mutants of the $\mathrm{O}^{\circ}$ type (Jacob and Monod, $\mathrm{I}_{96 \mathrm{I}}$ ) amongst the $m e t B$ and $F$ mutants would fail to complement all mutants of both genes if $m e t B$ and $F$ comprised the whole or part of an operon. In further abortive transduction tests none of the $3^{1}$ non-complementing metB mutants (group A, fig. 3) failed to complement $\mathrm{metF}_{3} 08,392$ and $4^{18}$ and none of the $25 \mathrm{met} F$ mutants failed to complement metB $39,340,345,36_{3}$ or $3^{82}$.

(2) What evidence is there that the relationship between the rates of synthesis of some or all of the methionine enzymes is constant i.e. that repression, if it occurs, is coordinate? Methionine certainly represses the synthesis of all the known enzymes of the methionine 
pathway in $S$. typhimurium except the cystathionase (Foster, personal communication; Rowbury, $1964 b$ and personal communication) but it is not known if this repression is coordinate.

(3) Is it likely that there is a cytoplasmic repressor substance acting upon one or more methionine genes whose synthesis is controlled by a gene located away from the operon(s)? A specific enzyme is not associated with the $m e t G$ gene, the mutants of which exhibit a low level of activity of all the methionine enzymes and map close together away from the other methionine genes (fig. 5). They could be repressor mutants producing a repressor with a reduced affinity for the methionine operator(s).

It is concluded that at present there is no immediately obvious compatibility with an operon model for the control of methionine biosynthesis in S. typhimurium. Further information is being obtained through studies of the mutants unable to carry out the indirect methylation of homocysteine (Childs and Smith, unpublished) and mutants of wild type whose growth is resistant to inhibition by analogues of methionine (Lawrence, personal communication). Some of the latter mutants may be of the derepressed or $\mathrm{O}^{\mathrm{C}}$ type (Jacob and Monod, I $96 \mathrm{I})$. It is hoped to investigate the possibility of coordinate repression of the methionine enzymes by methionine and to attempt their purification.

\section{SUMMARY}

Correlation of the results of growth response and transduction studies using 243 spontaneous or induced methionine mutants of Salmonella typhimurium with parallel detailed biochemical investigation of the enzymic deficiencies of a selected few of these mutants led to the recognition of 5 structural genes (met $A, B, C, E$ and $F$ ) and probably one regulator gene $(m e t G)$. Transduction analysis of all the mutants of each gene was carried out. A deletion map of the metA gene could be constructed but it was ambiguous. No interallelic complementation (abortive transduction) occurred between the mutants of the met $A$ and $F$ genes, but the met $E$ mutants fell into two complementation groups and the metB, $C$ and $G$ mutants into 12, 7 and 3 groups respectively. Unambiguous complementation maps of the metB and $C$ genes could be constructed. The $m e t G$ gene was not co-transducible with either the met $A, B, C$ or $E$ genes. This, and the results of previous transduction experiments, was in accordance with the separate location of all but the $m e t B$ and $F$ genes on the linkage map of $S$. typhimurium. The establishment of the pathway of methionine biosynthesis, the nature of the genes and enzymes concerned, and the relative susceptibility of methionine genes to the action of different mutagens are discussed and the mode of control of methionine biosynthesis considered.

Acknowledgments. - We are indebted to Dr M. Demerec and his colleagues (Department of Biology, Brookhaven National Laboratory, Upton, Long Island, New York, U.S.A.) for supplying the majority of mutants used in this work. We gratefully 
acknowledge discussion with Drs E. H. Creaser (Department of Microbiology, University of Birmingham) and M. A. Foster (Microbiology Unit, Department of Biochemistry, Oxford). Thanks are due to Mrs Angela Evans for excellent technical assistance. One of us (J.D.C.) was supported by a D.S.I.R. Research Studentship and included some of this work in a Ph.D. thesis submitted to the University of Birmingham in 1964 .

\section{REFERENCES}

Ames, B. N., ANd hartman, P. E. 1963. The histidine operon. Cold. Spr. Harb. Symp. quant. Biol., 28, 349-356.

AMES, B. N., AND MARTIN, R. G. 1964. Biochemical aspects of the gene: the operon. Ann. Rev. Biochem., 33, 235-258.

BEnzer, s. 1957. The elementary units of heredity. The Chemical Basis of Heredity. Johns Hopkins Press, Baltimore.

CAtCheside, D. G. 1960. Relation of genotype to enzyme content. Symp. Soc. gen. Microbiol., $10,18 \mathrm{I}-207$.

CHILDS, J. D. I964. Suppression, complementation and recombination studies of methionine and other mutants of Salmonella typhimurium. Ph.D. thesis, University of Birmingham.

CRICK, F. H. C., AND ORGEL, L. E. I964. The theory of inter-allelic complementation. 7. Mol. Biol., 8, 16 $1-165$.

DEMEREC, M., BLOMSTRAND, I., AND DEMEREC, z. E. 1955. Evidence of complex loci in Salmonella. Proc. nat. Acad. Sci. Wash., 4I, 359-364.

DEMEREC, M., AND DEMEREC, z. E. I 955 . Analysis of linkage relationships in Salmonella by transduction techniques. Brookhaven Symp. Biol., 8, 75-87.

Demerec, M., and hartman, P. E. 1959. Complex loci in microorganisms. Ann. Rev. Microbiol., 13, 377-406.

Fincham, J. R. S. 1962. Genetically determined multiple forms of glutamic dehydrogenase in Neurospora crassa. 7. Mol. Biol., 4, 257-274.

Flavin, M., DelaVier-klutchko, C., AND SLAUGHTER, c. I964. Succinic ester and amide of homoserine: some spontaneous and enzymatic reactions. Science, $143,50-52$.

FRERSE, E. 1959. The difference between spontaneous and base-analogue induced mutations of phage T4. Proc. nat. Acad. Sci. Wash., 45, 622-633.

GLANVILlE, E. V., AND DEMEREc, M. 196o. Threonine, isoleucine and isoleucinevaline mutants of Salmonella typhimurium. Genetics, 45, I359-1374.

GLOVER, S. W. 1958. A genetical and biochemical study of methionine mutants of Salmonella typhimurium. Proc. VIIth int. Con. Microbiol., 4 I, 57.

GUEST, J. R., FRIEDMAN, s., AND Foster, M. A. I962. Alternative pathways for the methylation of homocysteine by Escherichia coli. Biochem. F., 84, 93 P.

HARTMAN, P. E. 1956. Linked loci in the control of consecutive steps in the primary pathway of histidine synthesis in Salmonella typhimurium. Genetic Studies with Bacteria. Publ. Carneg. Instn., 612, 35-61.

haRTMAN, P. E., haRTMAN, z., AND ŠERMAN, D. 1960. Complementation mapping by abortive transduction of histidine requiring Salmonella mutants. J. gen. Microbiol., 22, 354-368.

HARTMAN, P. E., LOPER, J. C., AND ŠERMAN, D. I96o. Fine structure mapping by complete transduction between histidine-requiring Salmonella mutants, F. gen. Microbiol., 22, 323-353.

JACOB, F., AND MONOD, J. $196 \mathrm{I}$. Genetic regulatory mechanisms in the synthesis of proteins. 7. mol. Biol., 3, 318-356.

MARGolin, P. 1963. Genetic fine structure of the leucine operon in Salmonella. Genetics, $48,44 \mathrm{I}-457$.

ROWBURY, R. J. I $964 a$. The accumulation of $O$-succinylhomoserine by Escherchia coli and Salmonella typhimurium. 7. gen. Microbiol., 37, I 7 I-I8o. 
ROWBURy, R. J. I964b. Synthesis of cystathionine and its control in Salmonella typhimurium. Nature Lond., 203, 977-978.

ROWBURY, R. J., AND WOODs, D. D. 1964 . $O$-succinylhomoserine as an intermediate in the synthesis of cystathionine by Escherchia coli. 7. gen. Microbiol., 36, 34 I-358. SANDERSON, K. E., AND DEMEREC, M. 1965. The linkage map of Salmonella typhimurium. Genetics, 5I, 897-913.

sмrтн, D. A. 196r. Some aspects of the genetics of methionineless mutants of Salmonella typhimurium. 7. gen. Microbiol., 24, 335-353.

szulmajster, J., AND woods, D. D. I960. The synthesis of methionine from homocysteine by enzymic extracts of Escherchia coli. Biochem., 7. 75, 3-1 2.

WIJESUNDERA, S., AND WOODS, D. D. 1962. The catabolism of cystathionine by Escherchia coli. 7. gen. Microbiol., 29, 353-366.

WOODS, D. D., FOSTER, M. A., AND GUEST, J. R. 1965. Cobalmin-dependent and independent methyl transfer in methionine biosynthesis. Transmethylation and methionine biosynthesis. University of Chicago. I38-154. 